\title{
Protective role of melatonin on the effect of diazepam on proliferative activity, morphological changes and testosterone levels in the testes of rats
}

Gamal H. El-Sokkary ${ }^{1 *}$, Hemmat H. G. Hareedy² and Hala A.M. Youns ${ }^{1}$

*Correspondence: gelsokkary@yahoo.com

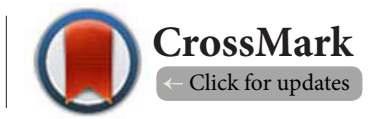

'Department of Zoology Faculty of Science, Faculty of Science Assiut University Assiut, 71516, Egypt.

${ }^{2}$ Department of Medical Histology, Faculty of Medicine, Assiut University Assiut, 71516 Egypt.

\begin{abstract}
Objective: There are evidences indicating that diazepam administration inhibits cell proliferation both in vitro and in vivo. The benefits of melatonin against diazepam-induced proliferative activity, morphological and level of testosterone changes were investigated in this study.

Materials \& methods: Three equal-sized groups of male rats [control, diazepam $(3 \mathrm{mg} / \mathrm{kg})$ and diazepam plus melatonin $(10 \mathrm{mg} / \mathrm{kg})]$ were used. Levels of testosterone hormone in the serum were measured. Cell proliferation was detected by autoradiography and the morphological alterations were investigated.

Results: Results documented decreased both ${ }^{3} \mathrm{H}$-labelling index (proliferative activity) and the levels of testosterone with marked histopathological alterations in the seminiferous tubules of diazepamadministered rats versus those of controls. When melatonin was given to diazepam-administered rats, it stimulates the decrease of labelling index, restored the levels of testosterone and preserves the alterations and number of different germ cell types in all stages of the seminiferous tubules.

Conclusion: These results suggest long-term hazard in use of drugs such as diazepam may be toxic and damage terminates in complex testes dysfunction and infertility. Furthermore, melatonin may be useful in combating testes injury resulting from hazard and/or repeated diazepam administration.
\end{abstract}

Keywords: Melatonin, diazepam, ${ }^{3} \mathrm{H}$-labelling index, seminiferous tubule

\section{Introduction}

Benzodiazepines (BDZ) are the most frequently prescribed class of psychotropic drugs may be worldwide [1]. Benzodiazepines, such as diazepam, are commonly used for their sedative and anxiolytic effects, i.e., by their action on high affinity receptor sites coupled to gammaaminobutyric acid A (GABA-A) receptor complex, present in the central nervous system (CNS) [2]. In addition to the central receptors described for BDZ, peripheral-type binding sites (PBRs) have been identified for them in liver cells [3], endocrine steroidogenic tissues [4] and immune cells, such as macrophages and lymphocytes [5], and also in tumor cells $[6,7]$.

Peripheral-type benzodiazepine receptor expression has also been associated with both tumor progression and aggressive- ness, since higher levels of its expression were found in tumor cells that display increased rate of proliferation, such as breast cancer cells [6], hepatic cancer cells [8] and glioma cells [9].

There are many evidences indicating that diazepam inhibits cell proliferation both in vitro and in vivo. Clark and Ryan [10] reported that diazepam exerted an antiproliferative effect on 3T3 fibroblasts. The antiproliferative action of diazepam on the proliferation of mouse spleen lymphocytes in vitro was noticed by Pawlikowski et al. [11,12]. Also, it was found that diazepam inhibited the in vitro proliferation of rat $\mathrm{C} 6$ glioma and mouse neuroblastoma cells [13] and cerebral cortical neurons [14]. In vivo studies of Pawlikowski et al. [15] showed that diazepam decreased the mitotic activity of the parietal cerebral cortex and the anterior pituitary gland in rats. Diazepam administration

(c) 2018 El-Sokkary et al; licensee Herbert Publications Ltd. This is an Open Access article distributed under the terms of Creative Commons Attribution License (http://creativecommons.org/licenses/by/3.0). This permits unrestricted use, distribution, and reproduction in any medium, provided the original work is properly cited. 
was shown to inhibit the mitotic index of the adrenocortical cells [16] and suppress the proliferation of spleen lymphocytes in rats [17]. In contrast, El-Sokkary [18] found increased labelling index and ${ }^{3} \mathrm{H}$-thymidine incorporation (DNA synthesis) in the liver of rats administered with diazepam. Diazepam had antifertility effects on male rats through attenuating steroidogenesis and testosterone production by inhibiting the pituitary gonadal axis hormones and the StAR gene expression through its effects on calcium ions [19].

Melatonin, a hormone which is synthesized by the pineal gland, is a potent antioxidant $[20,21]$. Although melatonin altered the spermatogenesis, it could not change the morphometric parameters such as tubular diameter and heights of the epithelium significantly [22]. Melatonin, by having lipophilic and hydrophilic compounds, can pass freely from the morpho-physiological barrier of different organs [23]. The direct effect of melatonin was observed in the male reproductive system and in the synthesis of testosterone from the Leydig cells in animals [24].

In general, it is accepted that a higher percentage of motile sperm is associated with improved fertilization rates and Ortiz et al. has shown that the addition of melatonin to seminal samples can improve the overall motility and the percentage of progressively motile spermatozoa $[25,26]$. Melatonin also appears to inhibit apoptosis in spermatozoa, with a reduction in early apoptotic events being demonstrated in human sperm thus prolonging sperm survival [27]. These effects would serve to improve sperm quality, therefore increasing the probability of successful fertilization. Melatonin, through its neutralization of reactive oxygen and nitrogen species, has been shown in both animal and human studies to improve seminal quality in-vitro. Studies in rats have shown that melatonin has a positive effect on sperm that have been subjected to oxidative stress, improving sperm number, viability and motility $[\mathbf{2 8 , 2 9 ]}$. Similar results have been found in a small human study in which in-vitro melatonin-treated samples showed a higher percentage of sperm motility and a lower proportion of non-viable spermatozoa [30].

\section{Materials and Methods \\ Animals}

Thirty adult male Sprague-Dawley rats, weighing approximately $150 \mathrm{~g}$, were used in this work. The animals were housed conventionally in cages (3-4 rats per cage) and fed with standard food and tap water ad libitum. The rats were maintained in 12:12 light:dark cycle at constant temperature $\left(25 \pm 2^{\circ} \mathrm{C}\right)$. An automatic timer controlled light and dark exposure with lights off $19.00 \mathrm{~h}$ to $07.00 \mathrm{~h}$. The care and treatment of the animal was approved and performed according to the approval ethics of Assiut University.

\section{Chemicals}

Diazepam (Hoffman La Roche, Basel, Switzerland) and melatonin (Sigma Co. St. Louis MO) were suspended in few drops of ethanol and the final volumes adjusted with saline. Tritiated thymidine $\left(\left[{ }^{3} \mathrm{H}\right] \mathrm{TdR}\right)$ was purchased from PerkinElmer (Boston, MA). Kodak NTB ${ }_{2}$ emulsion, Kodak D-76 developer and Kodak fixer were from Eastman Kodak (Rochester, New York). Fertigenix-Testo-Easia kit (Biosource, USA). All other chemicals were of higher quality available.

\section{Experimental Design and procedures}

The rats were divided into three equal-sized groups 10 rats each. The first group served as control and given vehicle $(0.9 \%$ $\mathrm{NaCl}$ solution contained $0.5 \%$ ethanol) only. The second group was administered with diazepam ( $3 \mathrm{mg} / \mathrm{kg}$ ) according to ElSokkary [18]. The third group was given a similar injection of diazepam which was preceded, 30 min earlier, by melatonin administration (10 mg/kg) according to El-Sokkary et al. [20]. All of these injections were subcutaneously repeated daily for 30 days. At the end of the experiment, the rats were sacrificed and the testes were removed and fixed in 10\% neutral buffered formalin.

Autoradiography and quantitation of autoradiographs Twenty four hours after the last injections, 5 rats from each group received a subcutaneous injection of $1 \mathrm{uCi} / \mathrm{g}$ body weight of $\left[^{3} \mathrm{H}\right] \mathrm{TdR}$ and they were killed 2 hours later. Paraffin sections ( $5 \mathrm{~mm}$ thick) were prepared. The deparaffinized sections were dipped in Kodak $\mathrm{NTB}_{2}$ emulsion (diluted 1:1 with distilled water) and kept for 25 days in the dark at $4^{\circ} \mathrm{C}$. All autoradiographs were stained with Harris's haematoxylin and eosin. A spermatogonial cells were scored as being labelled when 5 or more grains located over their nuclei. All labelled and unlabelled spermatogonia in the 8 stages of the seminiferous tubules were counted. The ${ }^{3} \mathrm{H}$-labelling index (LI) was expressed as the percentage of labelled spermatogonia. The LI represent the kinetics of cellular proliferation [31].

\section{Measurement of serum testosterone}

Serum samples were collected for testosterone determination using ELISA. Levels were measured by using the above kit according to the manufacturer's instructions.

Histology and quantitation of seminiferous epithelial cycle and Leydig cells

5 rats from each group were sacrificed concomitantly with the previous rats and specimens of testes were taken, fixed, embedded in paraffin, sectioned and stained with haematox$y$ line and eosin. The identification of the different stages of seminiferous epithelial cycle (50 seminiferous tubules for each animal) was based on the morphological changes of the germ cell nuclei and the local arrangement of the spermatids [32,33].

The number of Leydig cells $/ \mathrm{mm}^{2}$ (unit area) was counted using the square grid (area/ $\mathrm{mm}^{2}$ ) at $1000 \mathrm{X}$ magnification and 35 unit areas were counted. The nuclear volume of the Leydig cells was performed using ocular micrometer at $1000 \mathrm{X}$ magnification. A total number of 300 nuclei were measured/animal. 
The measurement was carried out by concerning rounded nuclei of Leydig cells where the formula of the sphere was applied $(\mathrm{V}=4 / 3 \pi \mathrm{R} 3)$, where $\mathrm{R}=$ nuclear diameter $/ 2$.

\section{Statistical analysis}

Quantitative results were expressed as means \pm S.E.M. Differences between means were tested by one way analysis of variance (ANOVA) followed by the Student-Newman-Keuls t-test. The percent of stimulation (S\%) or inhibition (I\%) in the mean values was calculated.

\section{Results}

\section{The seminiferous tubules}

In the diazepam-treated rats, the diameters of seminiferous tubules decreased and their architecture was altered (Figures 2 and 5) when compared with those of control animals (Figures 1 and 4). A lot of degenerating germ cells that contain vacuoles of varying sizes, congested blood vessels and peritubular edema were detected in large number of seminiferous tubules of diazepam-treated rats as shown in Figures $\mathbf{2}$ and $\mathbf{5}$. Also, the number of germ cells in all stages of the seminiferous tubule markedly decreased in diazepam-treated rats compared to those of controls (Figure 5). Melatonin administration to diazepam-treated rats restored the changes of the germ cells towards those of controls (Figures 3 and $\mathbf{6}$ ).

The quantitative results of the seminiferous tubules cycles are presented in Table 1. Statistically, there was a significant reduction $(P<0.01)$ in the mean number of different germ cell types in all stages of the seminiferous tubules in diazepamtreated rats versus those of control animals. When melatonin was given to diazepam-treated animals, the number of different germ cell types in all stages of the seminiferous tubules was significantly increased $(P<0.01)$ and appeared near to those of control numbers.

\section{The interstitial cells of Leydig}

As seen in Figure $\mathbf{2}$ there was a sharp drop in the number of Leydig cells in the testes of diazepam-treated rats when

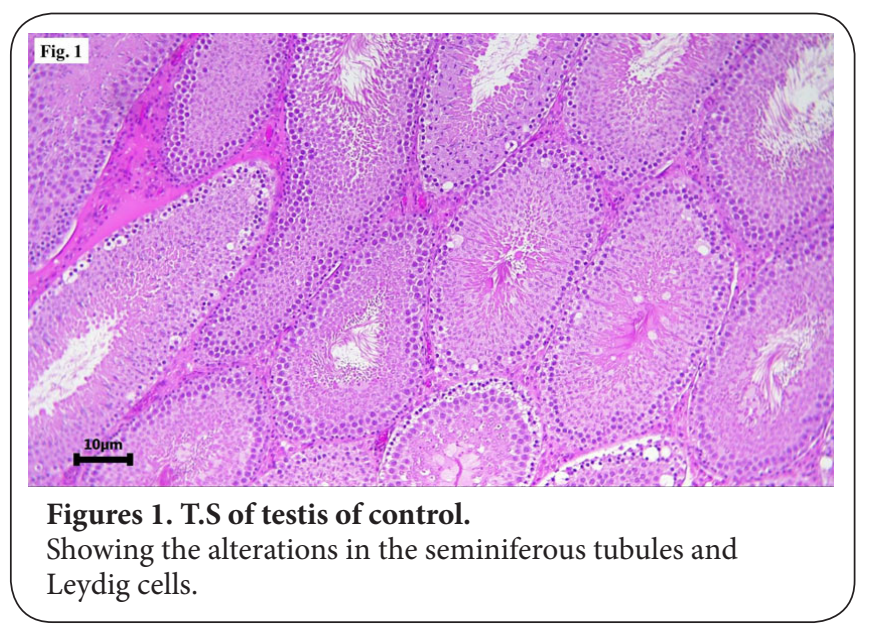

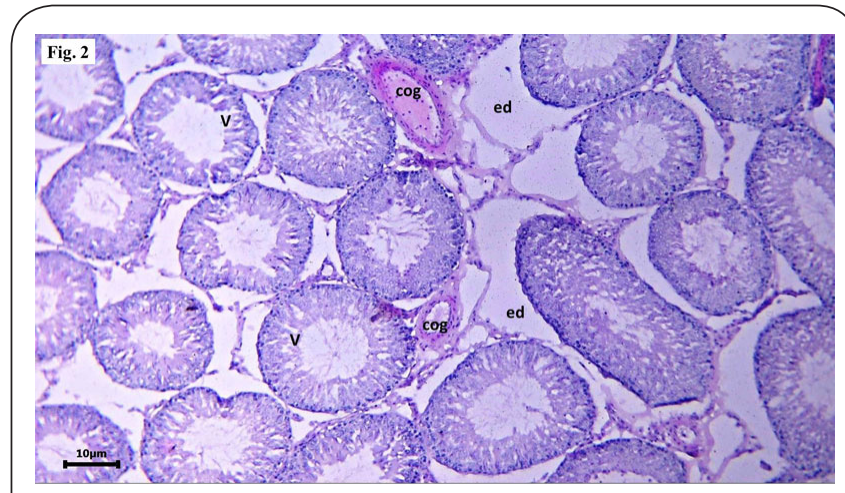

Figure 2. Diazepam-treated.

Showing the alterations in the seminiferous tubules and Leydig cells. V: vacuoles, ed: edema, cog: congested blood vessels (H\&E).

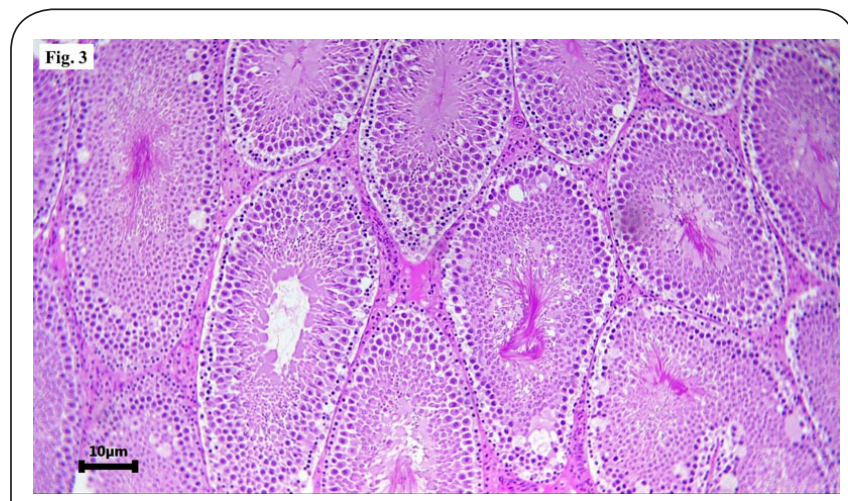

Figure 3. Diazepam +melatonin treated rats.

Showing the alterations in the seminiferous tubules and Leydig cells.

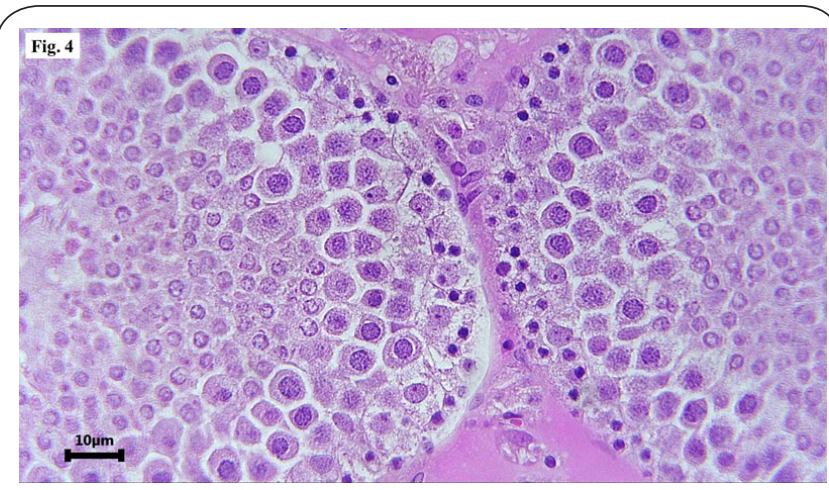

Figure 4. T.S of testis of control.

Showing different stages the seminiferous tubule cycle (H\&E).

compared with those of controls (Figure 1). The quantitative results of the number and nuclear volume of Leydig cells 


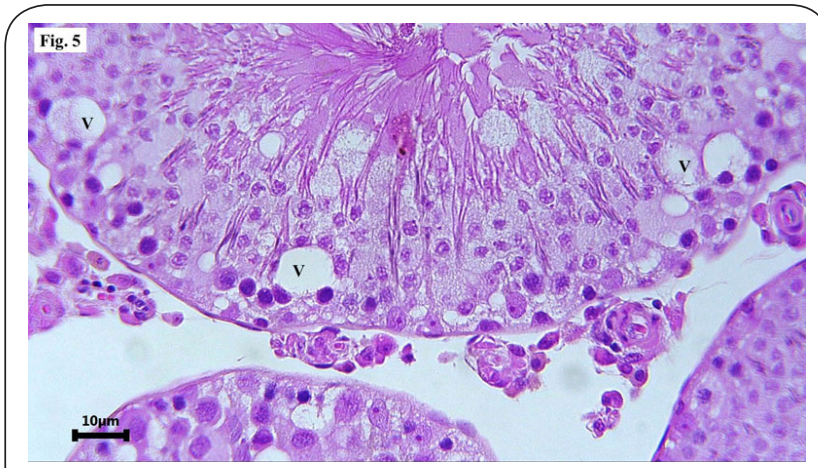

Figure 5. Diazepam-treated.

Showing different stages the seminiferous tubule cycle (H\&E). The stages of the diazepam-treated rats present several degenerative germ cells and vacuoles $(V)$.

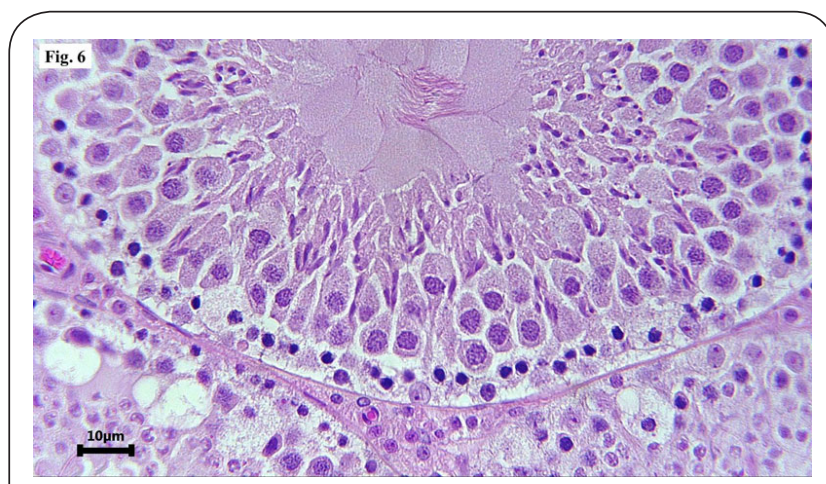

Figure 6. Diazepam +melatonin treated rats.

Showing different stages the seminiferous tubule cycle (H\&E). are presented in Table 2. As shown, there was a significant decrease $(P<0.01)$ in the mean number of Leydig cells $/ \mathrm{mm}$ (unit area) in diazepam-treated rats versus controls. Also, the quantitative data revealed that there was a significant reduction $(\mathrm{P}<0.01)$ in the mean volume of nuclei of Leydig cells in diazepam-treated rats versus controls. Again, melatonin administration to diazepam-treated animals increased both of the mean number of Leydig cells and the mean volume of their nuclei. The stimulation in the two parameters was significant $(P<0.01)$.

\section{Testosterone concentration}

Serum testosterone concentrations were significantly decreased $(P<0.01)$ by $36 \%$ in diazepam-treated animals versus controls (Table 3 ). When melatonin was administered to diazepam-treated rats, it stimulated the concentration of testosterone hormone by $18.6 \%$. Statistically this stimulation was significant $(P<0.05)$.

\section{Autoradiography and spermatogonial proliferation} The number of labelled spermatogonia in the different stages of seminiferous tubule cycle was lower in diazepam-treated rats than those of controls, as shown in Figures $\mathbf{7}$ and 8 . The quantitative results of autoradiographic study are presented in Table 4. As shown, the mean ${ }^{3} \mathrm{H}$-labelling index (LI) was significant decreased $(P<0.01)$ in spermatogonia of each stage in the seminiferous tubule cycle of diazepam-treated rats versus those of controls. In addition, the mean value of $L I$ in the spermatogonia of all stages of the seminiferous tubule cycle as a whole decreased significantly $(\mathrm{P}<0.0 \mathrm{O})$ in rats given diazepam versus control ones. The above data revealed that there was a sharp suppression in the proliferative activity of

Table 1: Mean number of cells $( \pm$ S.E) in different stages of the seminiferous epithelial cycle in control and treated rats.

\begin{tabular}{|c|c|c|c|c|c|c|c|c|c|}
\hline \multirow{2}{*}{ Stages } & \multirow{2}{*}{ 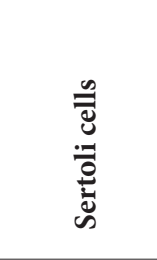 } & \multicolumn{3}{|c|}{ Spermatogonia } & \multirow{2}{*}{ क⿺辶ّ } & \multirow{2}{*}{ 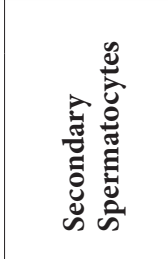 } & \multicolumn{2}{|l|}{ Spermatids } & \multirow{2}{*}{ 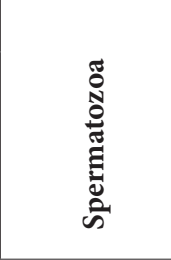 } \\
\hline & & Type A & Type B & Total & & & 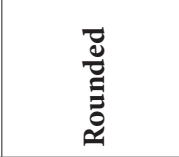 & 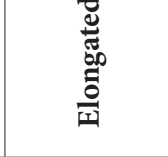 & \\
\hline Control group & $4.64^{\mathrm{a}} \pm 0.171$ & $28.7^{\mathrm{a}} \pm 0.981$ & $8.2^{\mathrm{a}} \pm 0.181$ & $36.9^{\mathrm{a}} \pm 0.932$ & $52.94^{\mathrm{a}} \pm 1.194$ & $7.84^{\mathrm{a}} \pm 0.182$ & $49.3^{\mathrm{a}} \pm 1.568$ & $9.86^{\mathrm{a}} \pm 0.293$ & $12.28^{\mathrm{a}} \pm 0.316$ \\
\hline DZ group & $2.52^{b} \pm 0.162$ & $17.8^{\mathrm{b}} \pm 0.762$ & $4.7^{\mathrm{b}} \pm 0.162$ & $22.5^{\mathrm{b}} \pm 0.814$ & $32.58^{\mathrm{b}} \pm 1.057$ & $3.24^{\mathrm{b}} \pm 0.101$ & $32.58^{\mathrm{b}} \pm 1.057$ & $8.3^{\mathrm{b}} \pm 0.179$ & $9.1^{\mathrm{b}} \pm 0.222$ \\
\hline $\mathrm{DZ}+$ melatonin & $3.68^{\mathrm{c}} \pm 0.165$ & $22.3^{c} \pm 0.684$ & $6.9^{c} \pm 0.244$ & $29.1^{\mathrm{c}} \pm 0.738$ & $43.6^{c} \pm 1.298$ & $5.42^{\mathrm{c}} \pm 0.172$ & $43.6^{c} \pm 1.298$ & $9.28^{\mathrm{a}} \pm 0.252$ & $10.98^{c} \pm 0.207$ \\
\hline
\end{tabular}

Values in the same column with unlike superscript letters are significantly differing at $\mathrm{P}<0.05$.

Table 2: Means of number and nuclear volume of Leydig cells in control and treated rats.

\begin{tabular}{|c|c|c|}
\hline $\begin{array}{l}\text { Measurements } \\
\text { Groups }\end{array}$ & $\begin{array}{l}\text { Mean number of } \\
\text { Leydig cells } \pm \text { SD }\end{array}$ & $\begin{array}{l}\text { Mean nuclear volume } \\
\left(\mathrm{mm}^{3}\right) \text { of Leydig cells } \pm \text { SD }\end{array}$ \\
\hline Control group & $24.8 \pm 4.3^{\mathrm{a}}$ & $89.6 \pm 8.2^{\mathrm{a}}$ \\
\hline DZ group & $12.2 \pm 2.3^{\mathrm{b}}$ & $43.5 \pm 5.2^{\mathrm{b}}$ \\
\hline $\mathrm{DZ}+$ melatonin & $17.6 \pm 1.9^{c}$ & $60.7 \pm 4.3^{c}$ \\
\hline
\end{tabular}

Values in the same column with unlike superscript letters are significantly differing at $\mathrm{P}<0.05$ 
Table 3: Means of testosterone concentrations $( \pm \mathrm{SE})$, inhibition $(\mathrm{I} \%)$ and/or stimulation (S\%) in control and treated rats.

\begin{tabular}{|l|c|c|c|c|c|c|}
\hline \multirow{2}{*}{ Animal group } & Control & \multicolumn{2}{|c|}{ DZ group } & \multicolumn{3}{c|}{ DZ+melatonin } \\
\cline { 2 - 7 } & & & I \% versus Cont. & & I \% versus Cont. & $\begin{array}{c}\text { S \% versus DZ } \\
\text { group }\end{array}$ \\
\hline Testosterone $(\mathbf{n g} / \mathrm{ml})$ & $0.857 \pm 0.02^{\mathrm{a}}$ & $0.548 \pm 0.02^{\mathrm{b}}$ & $\mathrm{I}=36.0$ & $0.673 \pm 0.02^{\mathrm{c}}$ & $\mathrm{I}=21.5$ & $\mathrm{~S}=18.5$ \\
\hline
\end{tabular}

Values in the same row with unlike superscript letters are significantly differing at $\mathrm{P}<0.05$.

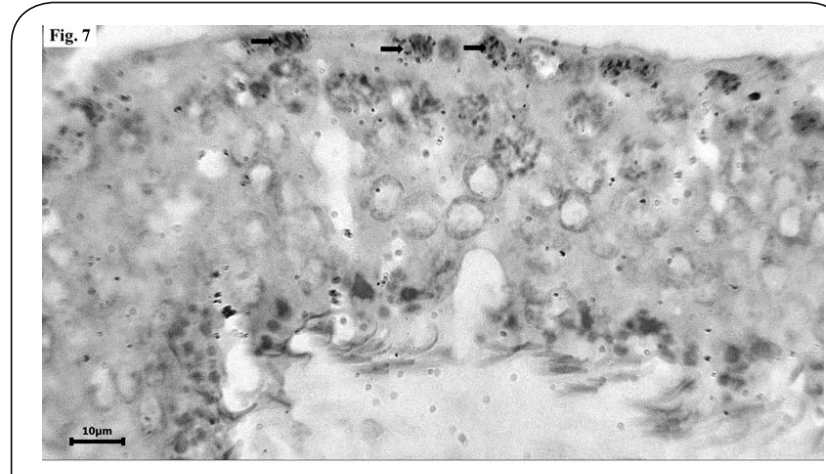

Figure 7. T.S of testis of control.

showing the distribution of labelled spermatogonia (arrows) in different stages of seminiferous tubule cycle (H\&E). the spermatogonia of diazepam-treated rats. When melatonin administered to the diazepam-treated rats, it was blocking the inhibitory property of diazepam in the proliferative activity. The number of labelled spermatogonia in the different stages of seminiferous tubule cycle was increased than those of diazepam-treated rats (Figure 9). As seen in Table 4, the LI was significant increased $(P<0.01)$ in spermatogonia of each stage in the seminiferous tubule cycle.

\section{Discussion}

The results presented above showed clearly that diazepam administration had suppressed the proliferative activity of the spermatogonia. Various factors may be involved in the mechanisms of the inhibitory effect of diazepam on cell proliferation. It was reported that diazepam can affect the secretion of ACTH. Racagni et al [34] found that diazepam decreased

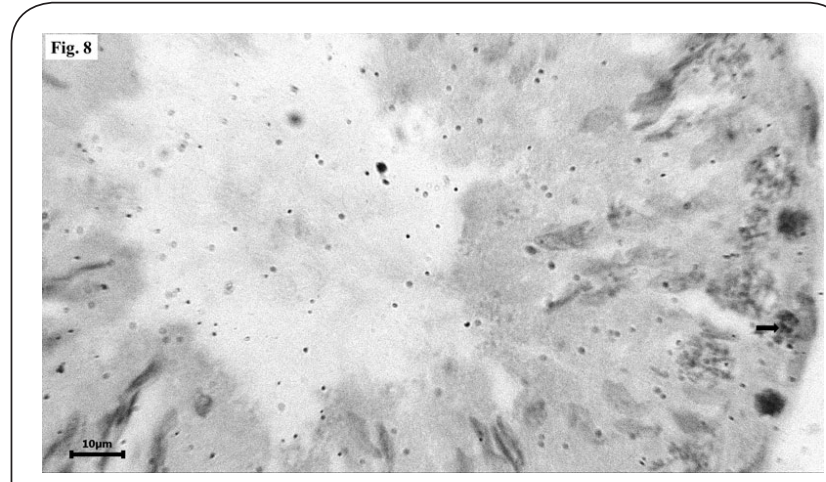

Figure 8. Diazepam-treated.

showing the distribution of labelled spermatogonia (arrows) in different stages of seminiferous tubule cycle $(\mathrm{H} \& \mathrm{E})$. The $3 \mathrm{H}$-labeeled spermatogonia sharply decreased in diazepamtreated rats.

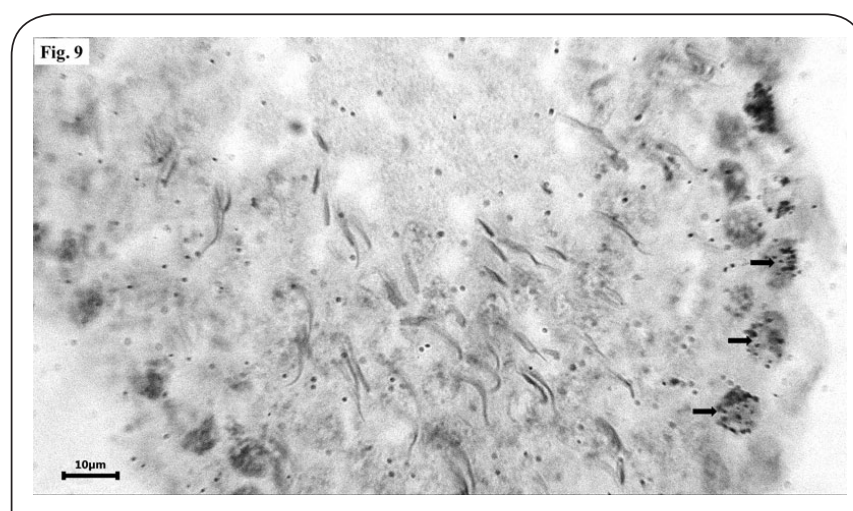

Figure 9. Diazepam + melatonin treated rats.

showing the distribution of labelled spermatogonia (arrows) in different stages of seminiferous tubule cycle (H\&E).

Table 4: Mean $3 \mathrm{H}$-labelling indices $( \pm \mathrm{SE})$ in spermatogonia of all stages of seminiferous tubules in control and treated rats.

\begin{tabular}{|l|c|c|c|c|c|c|c|c|c|}
\hline \multicolumn{1}{r|}{ Stages } & I & II & III & IV & V & VI & VII & VIII & Mean \\
\hline Control group & $17.1^{\mathrm{a}} \pm 0.037$ & $9.9^{\mathrm{a}} \pm 0.40$ & $11.8^{\mathrm{a}} \pm 0.38$ & $17.7^{\mathrm{a}} \pm 0.36$ & $12.2^{\mathrm{a}} \pm 0.37$ & $21.4^{\mathrm{a}} \pm 0.43$ & $18.2^{\mathrm{a}} \pm 0.34$ & $11.2^{\mathrm{a}} \pm 0.33$ & $14.9^{\mathrm{a}} \pm 1.47$ \\
\hline DZ group & $8.25^{\mathrm{b}} \pm 0.20$ & $6.45^{\mathrm{b}} \pm 0.25$ & $7.1^{\mathrm{b}} \pm 0.27$ & $8.56^{\mathrm{b}} \pm 0.22$ & $6.5^{\mathrm{b}} \pm 0.28$ & $9.15^{\mathrm{b}} \pm 0.21$ & $8.54^{\mathrm{b}} \pm 1.05$ & $6.4^{\mathrm{b}} \pm 0.29$ & $7.62^{\mathrm{b}} \pm 0.40$ \\
\hline DZ+melatonin & $12.95^{\mathrm{c}} \pm 0.27$ & $8.05^{\mathrm{c}} \pm 0.22$ & $8.9^{\mathrm{c}} \pm 0.24$ & $11.35^{\mathrm{c}} \pm 0.38$ & $8.55^{\mathrm{c}} \pm 0.26$ & $15.4^{\mathrm{c}} \pm .0 .47$ & $13.85^{\mathrm{c}} \pm 0.28$ & $10.25^{\mathrm{c}} \pm 0.31$ & $11.16^{\mathrm{ac}^{\mathrm{c}} \pm 0.95}$ \\
\hline
\end{tabular}

Values in the same row with unlike superscript letters are significantly differing at $\mathrm{P}<0.05$. 
ACTH secretion; accordingly, the secretion of adrenocortical hormones decreased [35]. The inhibitory effect of diazepam on cell proliferation may due to the induction of chromosomes malsegregation. It was found that diazepam inhibit centrioles shifting and induces the formation of monopolar spindle during the metaphase-anaphase transition [36].

Another possibility, which does not exclude the preceding mechanisms, is the effect of diazepam on calcium ions. It was reported that $B Z D$ receptors block the voltage-dependent calcium channels [37]. It is well stablished that calcium ions are needed in the later $G_{1}$ phase of the cell cycle for the initiation of DNA synthesis [38]. Moreover, it was reported that BZD inhibits the calmodulin-dependent protein kinase in the brain. Jones et al. [39] found that the role of calcium in the initiation of DNA synthesis is mediated by the formation of calcium -calmodulin complex.

Our results showed that melatonin administration enhances the proliferative activity of the spermatogonia and the number of labelled cells increased matching those of controls. The fascinating feature of this hormone is that it makes the normal cells proliferate and makes the cancerous cells undergo apoptosis [40].

Increasing evidence demonstrates that melatonin has an anti-apoptotic effect [41-43]. In vivo, melatonin alleviated ischemia-reperfusion induced apoptosis in neural cells through repression of the mitochondrial permeability transition pore $[44,45]$. Wang et al. [46] found that melatonin attenuated lipopolysaccharide-induced apoptotic liver damage in mice [46]. Li et al. [47] reported that melatonin protected kidney grafts from ischemia/reperfusion injury through the repression of the apoptosis after experimental kidney transplantation. In the study of Ji el al. [48], they found that melatonin alleviated Cd-induced testicular histopathological damage. Importantly, the frequency of tubules with more than six apoptotic germ cells was significantly reduced when mice were administered with melatonin. In addition, melatonin significantly reduced the percentage of tubules with apoptotic germ cells and thenumber of apoptotic germ cells per tubule. Also, melatonin attenuated 2-bromopropane-induced testicular germ cell apoptosis in rats [49]. These data demonstrate that melatonin could protect against germ cell apoptosis in testes.

In the current study, degeneration in the cells of the seminiferous tubules, vacuolation in their cytoplasm,and reduced seminiferous epithelial layers, edema, and hyalinization of intertubular tissue were detected in diazepam treated animals. The same results was reported previously by other investigators $[\mathbf{5 0}, \mathbf{5 1}]$, who described the appearance of necrosis, degeneration, desquamation, disorganization, reduction in germinal cells, vacuolization in Sertoli cells, multinucleated giant cell formation, interstitial edema, and congestion in theintertubular tissue.

In the present study, the concomitant administration of melatonin with diazepam led to a marked improvement in the histopathological changes.
These changes were in agreement with those observed by some researchers [52-54], who reported that melatonin may alleviate cadmium-induced cellular stress and germ cell apoptosis in testes.

Moreover, Take et al. [55] evaluated the protective effect of melatonin against irradiation-induced damage to rat testes that included amelioration of germ-cell depletion and apoptotic changes. At the ultrastructural level, Hussein et al. [56] observed the disappearance of the characteristics of apoptosis (condensation of the nuclei, vacuolization of the cytoplasm, increased cytoplasmic density, and apoptotic bodies) when the irradiated animals were pretreated with melatonin.

A lot of studies have explained the possible mechanism of melatonin protection as being dependent on its antioxidative action. Lena and Subramanian [57] reported that melatonin has the ability to scavenge reactive species, which makes melatonin a potent antioxidant and a free radical scavenger. They concluded that melatonin could control the oxidative abuse by (i) directly scavenging a variety of radicals and ROS, (ii) inducing antioxidative enzymes which reduce the steadystatelevels of ROS, (iii) inhibiting nitric oxide synthase, which generates nitric oxide, and (iv) stabilizing cellmembranes that aid them in reducing oxidative damage.

Gutierrez-Cuesta et al. [58] reported that melatonin improved prosurvival signals and reduced pro-death signals. Zhang et al. [59] have suggested that melatonin may potentially attenuate testicular damage by improving morphological changes and reducing germ cell apoptosis in mice.

The development and growth of male reproductive ducts and semniferous tubules is dependent on the increase of testosterone concentration [60]. Testosterone is essential for the survival of the spermatogenic endothelium and the significant decrease in testosterone hormone causes an increase in sperms abnormal morphology and decrease in sperm viability [61].

The results of the present study had shown that treatment with diazepam led to significant decrease in testosterone level in serum of treated animals. Testosterone hormone is the principle male hormone; it is synthesized by Leydig cells from cholesterol [62]. This decrement of testosterone level may be due to the effect of diazepam on serum cholesterol which is a precursor of testosterone synthesis by its action on the Leydig cells [63]. Therefore, the decreased testosterone concentration produced by the drug could be explained either by direct effect at Leydig cell level or an indirect effect by disturbing the hormonal milieu at hypothalamic-pituitary axis [64].

The reduced level of the testosterone has been suggested as being caused by the oxidative damage to the Leydig cell population [65] and might be related to the decreased numbers of Leydig cells [66]. Melatonin is attracting increased attention in recent years due to its known ability to reduce oxidative stress [20], with negligible toxicity even in very high doses [67-69]. Melatonin is not only an effective hydroxyl radical 
scavenger [70] but also has the capacity to detoxify other ROS and reactive nitrogen species as well as their metabolites, peroxynitrous acid, and intermediates $\mathrm{H} 2 \mathrm{O} 2$ [71]. Moreover, MLT enhances the antioxidant potential of the cell by the upregulation of several antioxidant enzymes [72].

Melatonin treatment to diazepam-administered rats ameliorated the reduction in the testosterone level. The increase of testosterone level after melatonin administration to diazepam-treated rats lends credence to melatonin's protection against the primary causes of damage of the testis. Because testosterone plays a key role in the process of spermatocyte meiosis [73] and the relationship between melatonin and testosterone has been well documented [74], it is suggested that modulation of the testosterone level by this hormone potentially protected the meiosis of spermatocytes and production of normal sperm quality, and this effect might be attributed to its capacity to control cellular redox state.

Finally, in this study, it was found that melatonin could provide good protection against diazepam-induced testicular damage. Several clinical trials should be conducted in the future to combine melatonin treatment with other chemotherapeutic and toxic drugs to reduce their cellular damage and toxicity.

\section{Competing interests}

The authors declare that they have no competing interests.

\section{Authors' contributions}

\begin{tabular}{|l|c|c|c|}
\hline Authors' contributions & GHS & HHR & HAY \\
\hline Research concept and design & $\checkmark$ & $\checkmark$ & $\checkmark$ \\
\hline Collection and/or assembly of data & $\checkmark$ & $\checkmark$ & $\checkmark$ \\
\hline Data analysis and interpretation & $\checkmark$ & $\checkmark$ & $\checkmark$ \\
\hline Writing the article & $\checkmark$ & $\checkmark$ & $\checkmark$ \\
\hline Critical revision of the article & $\checkmark$ & $\checkmark$ & $\checkmark$ \\
\hline Final approval of article & $\checkmark$ & -- & -- \\
\hline Statistical analysis & $\checkmark$ & -- & -- \\
\hline
\end{tabular}

\section{Publication history}

EIC: Gaetano Giuseppe Magro, University of Catania, Italy. Received: 01-Jan-2018 Final Revised: 03-Feb-2018

Accepted: 12-Mar-2018 Published: 24-Mar-2017

\section{References}

1. Stiefel F, Berney A and Mazzocato C. Psychopharmacology in supportive care in cancer: a review for the clinician. I. Benzodiazepines. Support Care Cancer. 1999; 7:379-85. | PubMed

2. Costa $E$, Guidotti $A$, Mao CC and Suria A. New concepts on the mechanism of action of benzodiazepines. Life Sci. 1975; 17:167-85. | PubMed

3. Woods MJ, Zisterer DM and Williams DC. Two cellular and subcellular locations for the peripheral-type benzodiazepine receptor in rat liver. Biochem Pharmacol. 1996; 51:1283-92. I Article I PubMed

4. Zilz A, Li H, Castello R, Papadopoulos V and Widmaier EP. Developmental expression of the peripheral-type benzodiazepine receptor and the advent of steroidogenesis in rat adrenal glands. Endocrinology. 1999; 140:859-64. | Article | PubMed

5. Zavala F. Benzodiazepines, anxiety and immunity. Pharmacol Ther. 1997;
75:199-216. | Article | PubMed

6. Hardwick M, Fertikh D, Culty M, Li H, Vidic B and Papadopoulos V. Peripheral-type benzodiazepine receptor (PBR) in human breast cancer: correlation of breast cancer cell aggressive phenotype with PBR expression, nuclear localization, and PBR-mediated cell proliferation and nuclear transport of cholesterol. Cancer Res. 1999; 59:831-42. | Article I PubMed

7. Han Z, Slack RS, Li W and Papadopoulos V. Expression of peripheral benzodiazepine receptor (PBR) in human tumors: relationship to breast, colorectal, and prostate tumor progression. J Recept Signal Transduct Res. 2003; 23:225-38. | Article | PubMed

8. Corsi L, Geminiani E, Avallone R and Baraldi M. Nuclear locationdependent role of peripheral benzodiazepine receptor (PBR) in hepatic tumoral cell lines proliferation. Life Sci. 2005; 76:2523-33. | Article | PubMed

9. Brown RC, Degenhardt B, Kotoula M and Papadopoulous V. Location-dependent role of the human glioma cell peripheral-type benzodiazepine receptor in proliferation and steroid biosynthesis. Cancer Lett. 2000; 156:125-32. | Article | PubMed

10. Clarke GD and Ryan PJ. Tranquillizers can block mitogenesis in 3T3 cells and induce differentiation in Friend cells. Nature. 1980; 287:160-1. | PubMed

11. Pawlikowski M, Stepien $\mathrm{H}$ and Kunert-Radek J. Diazepam inhibits proliferation of the mouse spleen lymphocytes in vitro. Pol J Pharmacol Pharm. 1986; 38:167-70. | PubMed

12. Pawlikowski M, Lyson K, Kunert-Radek J and Stepien H. Effect of benzodiazepines on the proliferation of mouse spleen lymphocytes in vitro. J Neural Transm. 1988; 73:161-6. I PubMed

13. Regan CM, Gorman AM, Larsson OM, Maguire C, Martin ML, Schousboe $A$ and Williams DC. In vitro screening for anticonvulsant-induced teratogenesis in neural primary cultures and cell lines. Int J Dev Neurosci. 1990; 8:143-50. | PubMed

14. Regan CM, Gorman AM, Larsson OM, Maguire C, Martin ML, Schousboe $A$ and Williams DC. In vitro screening for anticonvulsant-induced teratogenesis in neural primary cultures and cell lines. Int J Dev Neurosci. 1990; 8:143-50. | PubMed

15. Pawlikowski M, Stepien H, Mroz-Wasilewska Z and Pawlikowska A. Effects of diazepam on cell proliferation in cerebral cortex, anterior pituitary and thymus of developing rats. Life Sci. 1987; 40:1131-5. I PubMed

16. Zieleniewski J, Nowakowska-Jankiewicz B and Stepien H. Influence of diazepam on regenerating adrenal cortex in Wistar rats. Cytobios. 1990; 61:85-8. | PubMed

17. Morsi GA. Autoradiographic studies on the effect of diazepam on the proliferation of rat spleen lymphocytes. J. Egpt. Ger. Soc. Zool. 1991; 6:229-244.

18. El-Sokkary GH. Melatonin and vitamin C administration ameliorate diazepam-induced oxidative stress and cell proliferation in the liver of rats. Cell Prolif. 2008; 41:168-76. I Article I PubMed

19. Taher MA, and Anber, Z.N. Effect of diazepam on the reproductive system in male rats. World J. Pharm. Pharm. Sci. 2015; 4:60-78.

20. El-Sokkary GH, Nafady AA and Shabash EH. Melatonin administration ameliorates cadmium-induced oxidative stress and morphological changes in the liver of rat. Ecotoxicol Environ Saf. 2010; 73:456-63. I Article | PubMed

21. El-Sokkary GH, Ismail, I.A. and Saber H.S. Bright face of melatonin against breast cancer progression and metastasis. Eur. J. Biomed. Pharm. Sci.(EJBPS). 2016; 3:105-113.

22. Mirhoseini M, Talebpour Amiri F, Karimpour Malekshah AA, Rezanejad Gatabi Z and Ghaffari E. Protective effects of melatonin on testis histology following acute torsion-detorsion in rats. Int J Reprod Biomed (Yazd). 2017; 15:141-146. | PubMed Abstract | PubMed FullText

23. Tahan G, Akin H, Aydogan F, Ramadan SS, Yapicier O, Tarcin O, Uzun H, Tahan $\mathrm{V}$ and Zengin K. Melatonin ameliorates liver fibrosis induced by bile-duct ligation in rats. Can J Surg. 2010; 53:313-8. | Article | PubMed Abstract | PubMed FullText

24. Reiter RJ. Functional diversity of the pineal hormone melatonin: its role 
as an antioxidant. Exp Clin Endocrinol Diabetes. 1996; 104:10-6. | Article I PubMed

25. Ortiz A, Espino J, Bejarano I, Lozano GM, Monllor F, Garcia JF, Pariente JA and Rodriguez $A B$. High endogenous melatonin concentrations enhance sperm quality and short-term in vitro exposure to melatonin improves aspects of sperm motility. J Pineal Res. 2011; 50:132-9. | Article | PubMed

26. Espino J, Ortiz A, Bejarano I, Lozano GM, Monllor F, Garcia JF, Rodriguez $A B$ and Pariente JA. Melatonin protects human spermatozoa from apoptosis via melatonin receptor- and extracellular signal-regulated kinase-mediated pathways. Fertil Steril. 2011; 95:2290-6. | Article | PubMed

27. Espino J, Bejarano I, Ortiz A, Lozano GM, Garcia JF, Pariente JA and Rodriguez $A B$. Melatonin as a potential tool against oxidative damage and apoptosis in ejaculated human spermatozoa. Fertil Steril. 2010; 94:1915-7. | Article | PubMed

28. Nasiraei-Moghadam S, Parivar K, Ahmadiani A, Movahhedin M and VaezMahdavi M. Protective effect of melatonin against inequalityinduced damages on testicular tissue and sperm parameters. Int J FertilSteril 2014; 7:313-322.

29. Liu C, Gao P, Xu SC, Wang Y, Chen CH, He MD, Yu ZP, Zhang L and Zhou Z. Mobile phone radiation induces mode-dependent DNA damage in a mouse spermatocyte-derived cell line: a protective role of melatonin. Int J Radiat Biol. 2013; 89:993-1001. | Article | PubMed

30. du Plessis SS, Hagenaar K and Lampiao F. The in vitro effects of melatonin on human sperm function and its scavenging activities on NO and ROS. Andrologia. 2010; 42:112-6. | Article | PubMed

31. Hamatani K, Kawahara A and Amano M. Quantitative study of deoxycytidine incorporation in large and small lymphocytes of the mouse. Cell Tissue Kinet. 1983; 16:557-70. I PubMed

32. Clermont $Y$. Kinetics of spermatogenesis in mammals: seminiferous epithelium cycle and spermatogonial renewal. Physiol Rev. 1972; 52:198-236. | Article | PubMed

33. Franca, L R, Ye, S-J, Ying, L, Sandberg, M and Russell L.D. Morphology of rat germ cells during spermatogenesis. Anat. Rec. 1995; 241:181-204.

34. Racagni G, Apud JA, Cocchi D, Locatelli V and Muller EE. GABAergic control of anterior pituitary hormone secretion. Life Sci. 1982; 31:82338. | PubMed

35. Guyton C.A. The adrenocortical hormones. In: Textbook of Medical Physiology. Dreibelbis, D. (ed), W.B. Saundars Company Philadelphia. 1986; 909-922.

36. Callaini G, Dallai R and Riparbelli MG. Diazepam induces abnormal mitosis in the early Drosophila embryo. Biol Cell. 1989; 67:313-20. | Article | PubMed

37. Cantor EH, Kenessey A, Semenuk $G$ and Spector S. Interaction of calcium channel blockers with non-neuronal benzodiazepine binding sites. Proc Natl Acad Sci U S A. 1984; 81:1549-52. | Article | PubMed Abstract PubMed FullText

38. Hesketh TR, Moore JP, Morris JD, Taylor MV, Rogers J, Smith GA and Metcalfe JC. A common sequence of calcium and $\mathrm{pH}$ signals in the mitogenic stimulation of eukaryotic cells. Nature. 1985; 313:481-4. | PubMed

39. Jones A, Boynton AL, MacManus JP and Whitfield JF. Ca-calmodulin mediates the DNA-synthetic response of calcium-deprived liver cells to the tumor promoter TPA. Exp Cell Res. 1982; 138:87-93. | Article | PubMed

40. Gholami M, Saki G, Hemadi M, Khodadadi A and Mohamma-di-Asl J. Effect of Melatonin on the Expression of Apoptotic Genes in Vitrifiedthawed Spermatogonia Stem Cells Type A of 6-Day-Old Mice. Iran J Basic Med Sci. 2013; 16:906-9. | PubMed Abstract | PubMed FullText

41. Feng $Z$ and Zhang JT. Melatonin reduces amyloid beta-induced apoptosis in pheochromocytoma (PC12) cells. J Pineal Res. 2004; 37:257-66. | Article I PubMed

42. Luchetti F, Canonico B, Curci R, Battistelli M, Mannello F, Papa S, Tarzia G and Falcieri E. Melatonin prevents apoptosis induced by UV-B treatment in U937 cell line. J Pineal Res. 2006; 40:158-67. | Article | PubMed
43. Choi SI, Joo SS and Yoo YM. Melatonin prevents nitric oxide-induced apoptosis by increasing the interaction between 14-3-3beta and p-Bad in SK-N-MC cells. J Pineal Res. 2008; 44:95-100. | Article | PubMed

44. Andrabi SA, Sayeed I, Siemen D, Wolf G and Horn TF. Direct inhibition of the mitochondrial permeability transition pore: a possible mechanism responsible for anti-apoptotic effects of melatonin. FASEB J. 2004; 18:869-71. | Article | PubMed

45. Jou MJ, Peng TI, Hsu LF, Jou SB, Reiter RJ, Yang CM, Chiao CC, Lin YF and Chen CC. Visualization of melatonin's multiple mitochondrial levels of protection against mitochondrial $\mathrm{Ca}(2+)$-mediated permeability transition and beyond in rat brain astrocytes. J Pineal Res. 2010; 48:2038. | Article | PubMed

46. Wang $\mathrm{H}, \mathrm{Xu}$ DX, Lv JW, Ning $\mathrm{H}$ and Wei W. Melatonin attenuates lipopolysaccharide (LPS)-induced apoptotic liver damage in D-galactosamine-sensitized mice. Toxicology. 2007; 237:49-57. | Article I PubMed

47. Li Z, Nickkholgh A, Yi X, Bruns H, Gross ML, Hoffmann K, Mohr E, Zorn M, Buchler MW and Schemmer P. Melatonin protects kidney grafts from ischemia/reperfusion injury through inhibition of NF-kB and apoptosis after experimental kidney transplantation. J Pineal Res. 2009; 46:36572. | Article | PubMed

48. Ji YL, Wang $\mathrm{H}$, Meng $\mathrm{C}$, Zhao XF, Zhang $\mathrm{C}$, Zhang $\mathrm{Y}$, Zhao $\mathrm{M}$, Chen $\mathrm{YH}$, Meng XH and Xu DX. Melatonin alleviates cadmium-induced cellular stress and germ cell apoptosis in testes. J Pineal Res. 2012; 52:71-9. Article | PubMed

49. Huang $F$, Ning $H$, Xin QQ, Huang $Y$, Wang $H$, Zhang ZH, Xu DX, Ichihara $\mathrm{G}$ and $\mathrm{Ye} \mathrm{DQ}$. Melatonin pretreatment attenuates 2-bromopropaneinduced testicular toxicity in rats. Toxicology. 2009; 256:75-82. | Article I PubMed

50. Jalali AS, Hasanzadeh S and Malekinejad H. Crataegus monogyna aqueous extract ameliorates cyclophosphamide-induced toxicity in rat testis: stereological evidences. Acta Med Iran. 2012; 50:1-8. | Article | PubMed

51. Tripathi DN and Jena GB. Astaxanthin inhibits cytotoxic and genotoxic effects of cyclophosphamide in mice germ cells. Toxicology. 2008; 248:96-103. | Article | PubMed

52. Ji YL, Wang $\mathrm{H}$, Meng $\mathrm{C}$, Zhao XF, Zhang $\mathrm{C}$, Zhang $\mathrm{Y}$, Zhao $\mathrm{M}$, Chen $\mathrm{YH}$ Meng XH and Xu DX. Melatonin alleviates cadmium-induced cellular stress and germ cell apoptosis in testes. J Pineal Res. 2012; 52:71-9. Article | PubMed

53. Jang SS, Kim WD and Park WY. Melatonin exerts differential actions on X-ray radiation-induced apoptosis in normal mice splenocytes and Jurkat leukemia cells. J Pineal Res. 2009; 47:147-55. | Article | PubMed

54. Tunon MJ, San Miguel B, Crespo I, Jorquera F, Santamaria E, Alvarez M, Prieto J and Gonzalez-Gallego J. Melatonin attenuates apoptotic liver damage in fulminant hepatic failure induced by the rabbit hemorrhagic disease virus. J Pineal Res. 2011; 50:38-45. | Article | PubMed

55. Take G, Erdogan D, Helvacioglu F, Goktas G, Ozbey G, Uluoglu C, Yucel $B$, Guney Y, Hicsonmez A and Ozkan S. Effect of melatonin and time of administration on irradiation-induced damage to rat testes. Braz J Med Biol Res. 2009; 42:621-8. | Article | PubMed

56. Hussein MR, Abu-Dief EE, Abou El-Ghait AT, Adly MA and Abdelraheem $\mathrm{MH}$. Morphological evaluation of the radioprotective effects of melatonin against $X$-ray-induced early and acute testis damage in Albino rats: an animal model. Int J Exp Pathol. 2006; 87:237-50. | Article | PubMed Abstract | PubMed FullText

57. Lena PJ and Subramanian P. Evaluation of the antiperoxidative effects of melatonin in ammonium acetate-treated Wistar rats. Pol J Pharmacol. 2003; 55:1031-6. | Pdf | PubMed

58. Gutierrez-Cuesta J, Tajes M, Jimenez A, Coto-Montes A, Camins A and Pallas M. Evaluation of potential pro-survival pathways regulated by melatonin in a murine senescence model. J Pineal Res. 2008; 45:497505. | Article | PubMed

59. Zhang K, Lv Z, Jia X and Huang D. Melatonin prevents testicular damage in hyperlipidaemic mice. Andrologia. 2012; 44:230-6. | Article | PubMed

60. Guillete L.J., Pickford D.B., Crain D.A. and Percival H.F. Reduction in penis size and plasma testosterone concentration in juvenile alligators living 
in a contaminated environment. Gen. and Comp.Endocrine. 1996; 101: 32-42.

61. Einstein R., Jones R.S., Knifton A. and Srarmer G.A. Principles of veterinary therapeutics. Singapore, Longman Scientific and technical, 1994: 288-89.

62. Chaudhary R., Ashish R.S. and Mali P.C. Reversible contraceptive efficacy and safety evaluation of ethanolic extract of Maytenusemargineta in male albino rats. J. pharm. Res. 2011; 4:213-16.

63. Sandeep G, Dheeraj A, Sharma NK, Jhade D and Bharti A. Effect of plumbagin free alcohol extract of Plumbago zeylanica Linn. root on reproductive system of female Wistar rats. Asian Pac J Trop Med. 2011; 4:978-84. | Article | PubMed

64. Pineda M. H. and Dooley M.P. McDonald s. Veterinary Endocrinology and reproduction. 5th ed. , lowa state press, A Blackwell publishing company. 2003; 17:239-56.

65. Aguilar-Mahecha A, Hales BF and Robaire B. Chronic cyclophosphamide treatment alters the expression of stress response genes in rat male germ cells. Biol Reprod. 2002; 66:1024-32. I PubMed

66. Nakamura D, Yanagiba Y, Duan Z, Ito Y, Okamura A, Asaeda N, Tagawa Y, Li C, Taya K, Zhang SY, Naito H, Ramdhan DH, Kamijima M and Nakajima T. Bisphenol A may cause testosterone reduction by adversely affecting both testis and pituitary systems similar to estradiol. Toxicol Lett. 2010; 194:16-25. I Article I PubMed

67. El-Sokkary GH, Abdel-Rahman GH and Kamel ES. Melatonin protects against lead-induced hepatic and renal toxicity in male rats. Toxicology. 2005; 213:25-33. | Article | PubMed

68. Gurpinar T, Ekerbicer N, Uysal N, Barut T, Tarakci F and Tuglu MI. The effects of the melatonin treatment on the oxidative stress and apoptosis in diabetic eye and brain. ScientificWorldJournal. 2012; 2012:498489. | Article | PubMed Abstract | PubMed FullText

69. Reiter RJ, Rosales-Corral SA, Manchester LC and Tan DX. Peripheral reproductive organ health and melatonin: ready for prime time. Int J Mol Sci. 2013; 14:7231-72. | Article | PubMed Abstract | PubMed FullText

70. Reiter RJ, Tan DX, Gitto E, Sainz RM, Mayo JC, Leon J, Manchester LC, Vijayalaxmi, Kilic E and Kilic U. Pharmacological utility of melatonin in reducing oxidative cellular and molecular damage. Pol J Pharmacol. 2004; 56:159-70. | Pdf | PubMed

71. Tan DX, Reiter RJ, Manchester LC, Yan MT, El-Sawi M, Sainz RM, Mayo JC, Kohen R, Allegra M and Hardeland R. Chemical and physical properties and potential mechanisms: melatonin as a broad spectrum antioxidant and free radical scavenger. Curr Top Med Chem. 2002; 2:181-97. I Article | PubMed

72. Fischer TW, Kleszczynski K, Hardkop LH, Kruse N and Zillikens D. Melatonin enhances antioxidative enzyme gene expression (CAT, GPx, SOD), prevents their UVR-induced depletion, and protects against the formation of DNA damage (8-hydroxy-20-deoxyguanosine) in ex vivo human skin. J. Pineal Res. 2013; 54:303-312.

73. Jin P, Wang X, Chang F, Bai Y, Li Y, Zhou R and Chen L. Low dose bisphenol A impairs spermatogenesis by suppressing reproductive hormone production and promoting germ cell apoptosis in adult rats. $J$ Biomed Res. 2013; 27:135-44. | Article I PubMed Abstract | PubMed FullText

74. Casao A, Cebrian I, Asumpcao ME, Perez-Pe R, Abecia JA, Forcada F, Cebrian-Perez JA and Muino-Blanco T. Seasonal variations of melatonin in ram seminal plasma are correlated to those of testosterone and antioxidant enzymes. Reprod Biol Endocrinol. 2010; 8:59. | Article | PubMed Abstract | PubMed FullText

\section{Citation:}

El-Sokkary GH, Hareedy HHG and Youns HAM. Protective role of melatonin on the effect of diazepam on proliferative activity, morphological changes and testosterone levels in the testes of rats.

J Histol Histopathol. 2018; 5:5.

http://dx.doi.org/10.7243/2055-091X-5-5 